\title{
Scientific study on feeding wild pigs and pork in Vietnam (Thai nguyen region)
}

\author{
B.T. Thom ${ }^{1 *}$, D.T.N. Huy ${ }^{2}$, N.T. Hang
}

\begin{abstract}
${ }^{1}$ Thai Nguyen University of Agriculture and Forestry, Vietnam; ${ }^{2}$ Banking University HCMC, Ho Chi Minh city Vietnam - International University of Japan, Japan; Thai Nguyen University, University of Information and Communication Technology, Vietnam;

*Corressponding author e-mail: buithithom@tuaf.edu.vn,
\end{abstract}

Journal of Livestock Science (ISSN online 2277-6214) 12: 268-275

Received on 10/7/21; Accepted on 20/8/21; Published on 12/9/21

doi. 10.33259/JLivestSci.2021.268-275

\begin{abstract}
Wild boars are omnivores and sometimes eat indiscriminately. Daily food is mushrooms, tubers, rice, rice, fruits, eggs, carrots, vertebrates. Thanks to the ability to eat a variety of foods, wild boar survives in many different environments, from deserts to mountainous areas. Animal foods are birds, mammals, amphibians, reptiles, carrion, insects, terrestrial arthropods, mollusks. Plant foods are roots, tubers, bark, grass, rice, and fruits. Other foods are feces, carnivores, mushrooms. This study will use qualitative analysis, synthesis and inductive methods, with statistic data, examines experiences from Asian countries such as Thailand and China and meanings to Vietnam case of feeding wild pigs. Among our results is relating to the amino acid requirement of pigs consists of two components, maintenance needs and production needs. Last but not least, through our analysis, authors suggest Ministries and government agencies will consider to facilitate export markets for wild pork meat in the northern region of Vietnam, for instance, in Thai nguyen city, esp. in the context during EVTA to help pork meat export to European market.
\end{abstract}

Key words: feeding wild pigs; wild pork meat; pig farming; Vietnam; Thai Nguyen 


\section{Introduction}

\section{Habitats of wild pigs}

Wild boars are often found in large areas, they live in herds, the number can be up to 100 animals, these herds are the offspring and juveniles. Lan et al (2021) specified that In case of Northern region of Vietnam, many provinces and cities such as Thai Nguyen that have much and enough conditions for feeding wild pigs in Thai Nguyen ecological environment. Feeding wild pigs and managing wild pork meat quality is meaningful in Vietnam, esp. in Thai Nguyen province as pork products can offer variety of tastes due to food processing and suitable for Vietnamese tastes and can export to the world widely. Herds of wild boar can travel together on long journeys to new settlements, but do not migrate. Wild boars are more active at night, at dusk and at dawn. When the boar matures, it will leave the herd and live independently.

Eating habit

Wild boars are omnivores and sometimes eat indiscriminately. Daily food is mushrooms, tubers, rice, rice, fruits, eggs, carrots, vertebrates. Thanks to the ability to eat a variety of foods, wild boar survives in many different environments, from deserts to mountainous areas. Animal foods are birds, mammals, amphibians, reptiles, carrion, insects, terrestrial arthropods, mollusks. Plant foods are roots, tubers, bark, grass, rice, and fruits. Other foods are feces, carnivores, mushrooms. Wild boars are active and become reckless if they feel threatened, they will use all their strength, fangs and body to chase and injure the enemy. Moreover, When the EU-Vietnam Free Trade Agreement (EVFTA) takes effect, the EU commits to eliminate $85.6 \%$ of tariff lines for Vietnamese goods, equivalent to $70.3 \%$ of the total export value of Vietnam to EU. (source: www.baodautu.vn, date24/6/2021).

Research questions:

Question 1: What are appropriate feeding mechanism for wild pigs? What are protein and amino acid requirements?

Question 2: What are food processing and recommendations?

The work done previously is summarized in table 1

Table 1- Summary of previous studies

\begin{tabular}{|l|l|l|}
\hline Authors & Year & Content, results \\
\hline Poligne et al & 2001 & $\begin{array}{l}\text { Boucane' is a traditional meat product from Re'union that is } \\
\text { obtained by salting, drying and hot smoking pork belly. }\end{array}$ \\
\hline Thanapongtharm & 2016 & $\begin{array}{l}\text { pig production in Thailand intensified significantly during the last } \\
\text { decade, with many economic, epidemiological and environmental } \\
\text { implications. }\end{array}$ \\
\hline $\begin{array}{l}\text { Thang, H.T., \& } \\
\text { Van, C. }\end{array}$ & 2006 & $\begin{array}{l}\text { there are different types of feeds. different diets, the content of } \\
\text { nitrogen forms in the intestinal chyme is different }\end{array}$ \\
\hline Hang, D.L & 2008 & $\begin{array}{l}\text { When the pig matures it will leave the herd and live independently } \\
\text { around 50-350 kg, with some domesticated pigs up to 450 kg. } \\
\text { Males are usually larger than females. Wild pigs have 4 pairs of } \\
\text { fangs and 6 pairs of breasts. }\end{array}$ \\
\hline Lander et al & 2020 & $\begin{array}{l}\text { Pigs have played a central role in the subsistence and culture of } \\
\text { China for millennia. }\end{array}$ \\
\hline
\end{tabular}

Beside, Pedrazzoli et al (2017) mentioned that the stomach content and samples of Longissimus dorsi muscle of 32 feral wild boars were collected in two different feeding areas (forest and farmland) of Umbria region (Italy). The animals from each feeding area were divided into two age classes: class 1 (12-24 months of age; $48 \mathrm{~kg}$ average weight) and class 2 (animals older than 2 years of age; $84 \mathrm{~kg}$ average weight). The major food categories consumed were hard mast and crops (89.02-75.98\%).

\section{Methodology}

Authors also use statistic and data to make analysis and propose solutions. Experiences in Vietnam food processing are also mentioned. Beside, Authors mainly use combination of quantitative methods and qualitative methods including synthesis, inductive and explanatory methods. Authors also refer to experiments in Vietnam in this field. 


\section{Results}

Characteristics of growth and sexual development of wild boars and hybrids Growth characteristics

Wild boars grow slowly and reach their maximum size depending on breed, environment and age. The European wild boar is usually much larger in stature than the Asian wild boar. While the Asian wild boar can only be $65-70 \mathrm{~cm}$ tall, 120 - $140 \mathrm{~cm}$ long, 70 - $150 \mathrm{~kg}$ in weight, the European wild boar can be up to 90 - $100 \mathrm{~cm}$ tall, $150-160 \mathrm{~cm}$ long, and weigh up to $200-350 \mathrm{~kg}$. Males are usually 20-30 $\mathrm{kg}$ larger than females. Newborn pigs are very small, weighing $0.5-0.7 \mathrm{~kg}, 15-25 \mathrm{~cm}$ long. Weaning age 55 - 60 days; The weight of piglets at weaning is $4-5 \mathrm{~kg} / \mathrm{head}$. The age of slaughter can be calculated from 8 to 10 months old. The weight of slaughter usually ranges from $25-35 \mathrm{~kg}$ depending on the needs of the market.

Table 2 - Wild pigs growing speed

\begin{tabular}{|c|c|c|}
\hline Month age & Weight (kg) & $\begin{array}{c}\text { Speed of growing } \\
\text { (g/days) }\end{array}$ \\
\hline $0-2$ & $0.5-5$ & $8.33-83.33$ \\
\hline $2-4$ & $10-12$ & $166.66-200.00$ \\
\hline $4-6$ & $15-25$ & $250.00-416.66$ \\
\hline $6-8$ & $25-35$ & $300.00-583.33$ \\
\hline $8-10$ & $40-50$ & $666.66-833.33$ \\
\hline
\end{tabular}

The growth rate (for wild boars that have been raised in Thailand and Vietnam) is slow (average is only about $0.15-0.3 \mathrm{~kg} /$ day). Physiological life span of wild boar lasts from 15 to 25 years.

\section{Food and feeding method}

Food is full of nutrients, not rancid, moldy. The daily intake of pregnant sows depends on the sow's condition. Skinny sows must increase feed, too fat sows must reduce mixed feed but must increase forage. In winter, when the temperature in the barn is $<150 \mathrm{C}$, sows need to eat more $(0.2-0.3 \mathrm{~kg} / \mathrm{day})$ to compensate for the energy lost due to cold resistance.

\section{Basic characteristics of the digestive physiology of pigs}

Pigs are omnivores with a single stomach. The gastric environment contains gastric juice secreted by the gastric glands. The gastric juice has a low $\mathrm{pH}$ environment suitable for pepsin activity to break down proteins into albumin, peptone products and a small amount of amino acids. The pig's small intestine is very long and has many digestive secretions such as: pancreatic juice, intestinal juice and bile, in which only pancreatic juice and intestinal juice contain enough enzymes to thoroughly digest nutrients in feed. Therefore, the small intestine is a digestive part full of enzymes that break down nutrients in food into the simplest nutrients, helping the body absorb directly through the intestinal wall into the bloodstream. Bile juice does not contain digestive enzymes, but it aids in digestive activities, especially fat digestion. The small intestine environment is alkaline and has a special structure, highly adapted to digestion and absorption of food.

Along the intestinal mucosa, there are developed intestinal glands that secrete intestinal secretions in a full-secretory fashion, that is, the glandular cells filled with enzymes fall directly into the intestinal cavity, creating an endogenous nitrogen source up to $30 \mathrm{~g} /$ day. This is a feature that affects the accuracy of the digestibility test results in pigs, which cannot be ruled out. In the large intestine of pigs, there is a symbiotic intestinal microflora in the cecum and colon that is capable of breaking down fibers. The large intestine does not secrete enzymes, but only continues to break down food by enzymes in the small intestine. This rate of digestion is high or low depending on the retention time in the large intestine (12-16 hours). Digestion fiber 14\%, digest protein $12 \%$, have $9 \%$ carbohydrates and 3\% lipids of the remaining nutrients digested by the large intestine. The main activity of the large intestine is the fermentation of fiber due to the action of the microflora in the cecum and colon and the decomposition of excess protein in food by rotten bacteria to form Crezon toxins. Fenol, Idol, Scatol. These toxins are absorbed into the bloodstream and detoxified in the liver. If these substances are too much, they will poison the liver and be excreted through feces, causing unpleasant rotten odors, polluting the environment, and also cause diarrhea in pigs (Hoang Toan Thang et al. 2006).

Thus, in all cases, fermentation by microorganisms in the caecum and colon of pigs produces microbial biomass that is excreted in the feces, and this nitrogen source, together with excess nitrogen in the feed, causes significant errors, important in determining the net digestibility of nitrogen in feed. This compels 
nutritionists to study exclusions in experimental methods to test digestibility. Digestive activity of pigs during the day is usually greater than at night, and the time the feed stays in the gastrointestinal tract in pigs is about 24 hours.

\section{Protein and amino acid requirements of pigs}

We already know that the protein requirement is the amino acid requirement. The amino acid requirement of pigs consists of two components, maintenance needs and production needs. Recognize that maintenance is not a physiological reality but a conceptual fit (Fuller, MF, (1989). Processes that generate a need for maintenance or need for production are parts of the associative transfer in which synthesis of organizational proteins is continued and broken down, the exchange of amino acids, keto acids and other metabolites, between tissues and organs and the resulting network of these exchanges determines the amino acid requirements of pigs. The amino acid requirements of pigs consist of two components, maintenance needs and production needs. In mature individuals this also means constant body mass, however in immature animals the mass is kept constant by keeping nutrition, promoting growth and continuing to increase body protein while body fat loss (Fuller et al., 1979). To maintain nitrogen balance it is necessary to supply amino acids at a rate equal to the rate at which they are lost through metabolism, secretion or excretion from the body. Mandatory loss processes arise through them, the following processes being the most important and quantitative in nature.

Synthesis of non-protein substances: Some of the essential amino acids cannot be used in the synthesis of physiologically important substances such as: Hormones, neurotransmitters and important products of biological transformation side. Important complementary amino acids are lysine, methionine (and cysteine), phenylalanine (primarily through tyrocine), histidine, and tryptophan.

Amino acids lost from epidermal cells: Loss of amino acids from epithelial cells occurs free amino acids and proteins. Since pigs are non-perspirants, loss through perspiration is expected to be minimal. In particular, skin and hair shed and are replaced continuously, estimated skin and hair nitrogen loss in pigs averaged $55 \mathrm{~kg}$ for a range of $0.25-0.50 \mathrm{~g} / \mathrm{d}$, depending on feeding. and ambient temperature. By extrapolation (Fuller, 1991) it is estimated that if feed were restricted to such a degree to stop growth, these losses would be reduced to approximately $1 \mathrm{~g} \mathrm{~N} / \mathrm{d}$ or $5 \mathrm{mg} / \mathrm{d}$. This is only about $2 \%$ of the total $\mathrm{N}$ needs to maintain. However, this estimate, which includes extensive extrapolation, is unlikely to be a direct estimate.

In contrast, much of this is dependent on proteolysis and a large proportion of amino acids are reabsorbed, estimates of minimal loss from the gastrointestinal tract have been carried out by determining amino acids enter the large intestine when animals are fed a protein-free diet.

In a nutshell, the maintenance requirement is the amount of protein that replaces the proteins that are required to be lost from the body consisting mainly of skin proteins and various nitrogen metabolism end products in the urine. Forced losses are generally assessed by determining nitrogen excretion when fed a protein-free diet and have a normal relationship to body mass. Whether or not this estimate is applicable to animals fed diets with normal levels of protein in the feed is not known. (source: Wild pigs project, Thom, et al, 2013)

\section{Interaction relationship between protein and metabolic energy}

There are many studies that suggest that the protein accumulation rate of pigs can be inhibited because the feeding process does not provide enough energy and protein. The rate of protein accumulation can be influenced relatively independently of the energy or protein the animal receives daily through food. When formulating diets for pigs, we must establish a balance between protein and energy in order to maximize protein accumulation and significantly reduce fat accumulation.

Changes in the content of some amino acids in the internal organs can be attributed to the energy and protein intake that affect blood and organ mass (Bikker et al. (1994). and related fractions increased with increasing energy intake. The mass of blood, kidney, pancreas and spleen also increased with increased protein intake Schulz and Oslage (1976), protein content in blood, digestive system and liver accounts for 5, 4 and 3\% respectively compared with whole body protein. When different levels of energy intake will greatly affect the content and composition of acids The content of lysine, threonine, histidine, tyrosine, aspartic acid and serine in the internal organs was 10 - 30\% higher, while cystine, leucine, phenylalanine valine was $40-$ $50 \%$ higher than that in the carcass and the organs. The content of methionine, arginine, isoleucine, glutamic acid and glycine in the carcass was $10-30 \%$ lower than that of the organ.

Thom \& Huy, (2021) stated raising pigs is also facing many obstacles, because wild boars are wild, domesticated more difficult than foreign pigs, and require a large area of land and a rich source of green 
food. Wild boars have good characteristics of adaptability, tolerance to harsh conditions in mountainous areas, taking advantage of natural food sources and low technical requirements.

Table 3- Results of evaluation of experimental pork quality

\begin{tabular}{|c|c|c|c|c|}
\hline \multirow[b]{2}{*}{ Order } & \multirow[b]{2}{*}{ Content } & Lot TN1 & Lot TN2 & Lot TN3 \\
\hline & & $\overline{\mathrm{X}} \pm m_{\overline{\mathrm{X}}}$ & $\overline{\mathrm{X}} \pm m_{\overline{\mathrm{X}}}$ & $\overline{\mathrm{X}} \pm m_{\overline{\mathrm{X}}}$ \\
\hline 1. & $\begin{array}{l}\text { Meat color after surgery } \\
\left(\text { Minolta L }{ }^{*}\right) \text { (brightnes) }\end{array}$ & $48.02 \pm 1.11$ & $\begin{array}{l}47.95 \pm \\
1.54\end{array}$ & $47.83 \pm 1.36$ \\
\hline 2. & Meat toughness $\left(\mathrm{kg} / \mathrm{cm}^{2}\right)$ & $4.85 \pm 1.23$ & $4.89 \pm 1.56$ & $4.95 \pm 1.25$ \\
\hline 3. & $\mathrm{pH}$ of tenderloin right after surgery & $6.8 \pm 0.32$ & $7.0 \pm 0.12$ & $7.1 \pm 0.15$ \\
\hline 4. & tenderloin $\mathrm{pH}$ after 45 minutes & $5.5 \pm 0.21$ & $5.3 \pm 0.24$ & $5.2 \pm 0.26$ \\
\hline 5. & Cholesterol (mmol/L) blood & $1.65 \pm 1.23$ & $2.15 \pm 0.91$ & $3.11 \pm 1.89$ \\
\hline 6. & Triglycerid (mmol/L) blood & $2.3 \pm 1.34$ & $2.8 \pm 0.98$ & $2.6 \pm 1.12$ \\
\hline
\end{tabular}

(source: Wild pigs project, Thom, et al, 2013)

Wild pork meat processing

Below figure shows us steps to make delicious grilled wild pork:

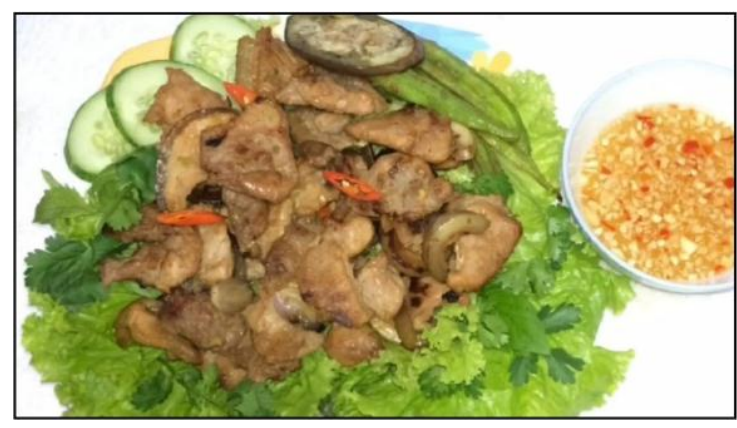

Fig 1- grilled wild pork meat fried (source: internet)



Fig 2 - Wild pork meat

Steps to make marinated wild boar meat

Marinate the pork with 2 tablespoons minced lemongrass, 2 tablespoons minced shallot, 1 tablespoon minced garlic, 1 tablespoon satay, 1 teaspoon minced chili.

Add 1 tablespoon seasoning, 1 teaspoon Ajinomoto or Vedan, 2 tablespoons cooking oil, 1.5 tablespoons honey, 1 teaspoon five spices, 2 tablespoons grilled marinade.

Mix well and marinate the meat for about 40 minutes for the meat to absorb the spices. Grilled wild boar is fragrant, pork is soft and sweet, not chewy, crispy skin, okra, eggplant just cooked to very sweet. 


\section{Discussion}

The role of food exchange energy in the survival of pigs

All living, developing and reproductive activities of pigs are associated with the process of using and exchanging energy. Energy in food is stored in the physical forms of food such as fat, sugar, protein, and carbohydrates. Pigs receive food energy from the outside, through digestion, absorption in the digestive tract into the body and synthesized into fat, glucose, and pure protein of the pig's body.

The pig's body wants to function like walking, breathing, circulating, digesting, excreting. All must use the energy stored in the body's fat, sugar, and protein to convert it into heat. Heat energy turns into function and acts on the body's organs to function in a rhythmic manner, through the control of nerves, hormones, and enzymes.

Energy participates in the construction of nerve cells, nerve sheaths, forming important compounds such as lipoproteit, glucoproteit found in nerve cell membrane tissue, in exocrine glands. Fat both stores energy and acts as a cushion under the skin, surrounding the digestive tract, circulation, and respiration to resist mechanical impact, heat and cold for the body. Pigs need more energy than other cattle because the genetic makeup of pigs accumulates fat about 45-50\% (Le et al., 2003).

The authors have focused a lot on research in the field: Determining the protein and energy needs of pigs to promote growth, complete development, reduce costs and increase livestock efficiency. The balance between protein/ME in pigs is an important requirement for growth, meat quality, and lean percentage at the growing stage of pigs.

Survey results on 77 wild boar breeding facilities across the country by the National Institute of Livestock Production showed that $61.1 \%$ of establishments raised pure Thai wild boar, 38.9\% of establishments raised many types, including wild boar. Thailand, Vietnam, native pigs and hybrids. There are 6 establishments that also raise pure Vietnamese wild boar. The Thai wild boar is imported from Thailand.

Research on the influence of protein level, energy, protein-energy relationship, with amino acids in the diet on pig growth and quality. Therefore, the balance of protein in the diet is a measure to supplement protein feed for wild boars, which is a measure to increase the efficiency of industrial-oriented hybrid wild boar farming to meet market demand. The research results of ARC (1981), Van de Ligt et al. (2002) studied the balance of amino acids and proteins in foreign crossbred pigs. Meat farming has given good results. Thus, the balance of protein and energy levels for hybrid wild boar to assess the growth ability through the stages, both to exploit the growth ability of high-quality wild boar, and to ensure naturalness. Their wildness is suitable for the northern climate conditions of Vietnam.

Kvisna et al (2005) studied the process of raising wild boar in Thailand with good results. Besides, Litten et al. (2004); Kuhn et al (2004) also studied that the addition of cassava flour to the wild boar's diet was effective but increased the percentage of fat higher than the addition to the corn-only diet.

With the practical requirements of Vietnam's wild boar farming and natural conditions, the research to determine the reasonable protein level in the diet based on local feed ingredients is an urgent requirement. Solving this urgent scientific problem not only ensures the maintenance of good growth performance for wild boars and hybrids, but also has the meaning of saving and taking initiative in food sources in large-scale wild boar and hybrid breeding. big is easy. In particular, it contributes to preserving and protecting precious pig genetic resources.

Ballari and Garcia (2013) stated that energy requirements, food availability, and seasonal and geographical variations are major factors influencing food selection by wild boar. These factors may also interact with human activities (e.g. agricultural crops, supplementary feeding) to influence diet composition further. Dietary studies should be more rigorous and consistent across ranges to allow better comparisons.

\section{Policy implications}

We would suggest that Ministries and government agencies will consider exploring export markets for wild pork meat in the northern region of Vietnam, for instance especially in Thai nguyen city. In the context during EVTA to help pork meat export to European market. Huy (2015) also suggested management standards for better management of businesses in various sectors including agriculture. The role of banks in financing industries including agriculture to promote economic sustainability is also important. It is recommended that when raising wild boar and crossbreeds, it is necessary to arrange more experiments with some other energy levels to evaluate more accurately. 


\section{References}

1) Bellary, S.A., \& Garcia, M.N.B. (2017). A review of wild boar Sus scrofa diet and factors affecting food selection in native and introduced ranges, Mammal Review 44(2). DOI:10.1111/mam.12015

2) Hac, L.D., Huy, D.T.N., Thach, N.N., Chuyen. B.M., Nhung, P.T.H., Thang, T.D., \& Anh, T.T. (2021). Enhancing risk management culture for sustainable growth of Asia commercial bank -ACB in Vietnam under mixed effects of macro factors, Entrepreneurship and Sustainability Issues, 8(3): 291-307.

3) Hang, D.L. (2008) (Department of Livestock Production). Some basic biological characteristics of wild boar. Livestock magazine February 2008.

4) Huy, D.T.N. (2021). Banking sustainability for economic growth and socio-economic development-case in Vietnam, Turkish Journal of computer and mathematics education, 12(2): 2544-2553.

5) Fuller M. F., Menie I., Crofts R. M. J. (1979), "The acid amin supplementation of barley for the growing pig”, 2, Optimal additions of lysine and threonine for growth. British Journal of Nutrition 41- 333.

6) Fuller, M.F., R.McWiliam, T.C.Wang, and L.R.Giles (1989), The optimum dietary acid amin pattern for growing pigs, 2. Requirements for maintenance and for tissue protein accretion. Br.J.Nutr. 62: 255-267.

7) Fuller, M. F, (1991), In Protein Metabolism and Nutrition: Proceeding of the $6^{\text {th }}$ International Symposium on Protein Metabolism and Nutrition, pp. 116-126. Edited by B.O. Eggum, S. Boisen, C. Borsting, A. Danfear and T. Hvelplund. E.A.A.P. Publication No. 59. Foulum: National Institute of Animal Science.

8) Hang, N.T., Tinh, D.T., Huy, D.T.N., \& Nhung, P.T.H. (2021). Educating and training labor force Under Covid 19; Impacts to Meet Market Demand in Vietnam during Globalization and Integration Era, Journal for Educators, Teachers and Trainers, 12(1): 179-184. DOI: 10.47750/jett.2021.12.01.023

9) Huy, D.T.N. (2015). The Critical Analysis of Limited South Asian Corporate Governance Standards After Financial Crisis, International Journal for Quality Research, 9(4): 741-764.

10) Huy, D.T.N. (2012). Estimating Beta of Viet Nam listed construction companies groups during the crisis, Journal of Integration and Development, 15 (1), 57-71

11) Huy, D. T.N., Loan, B.T., and Anh, P.T. (2020). 'Impact of selected factors on stock price: a case study of Vietcombank in Vietnam', Entrepreneurship and Sustainability Issues, 7(4):2715-2730. https://doi.org/10.9770/jesi.2020.7.4(10)

12) Huy, D. T.N., Dat, P.M., và Anh, P.T. (2020). 'Building and econometric model of selected factors' impact on stock price: a case study', Journal of Security and Sustainability Issues, 9(M): 77 93. https://doi.org/10.9770/jssi.2020.9.M(7)

13) Huy D.T.N., Nhan V.K., Bich N.T.N., Hong N.T.P., Chung N.T., Huy P.Q. (2021). 'Impacts of Internal and External Macroeconomic Factors on Firm Stock Price in an Expansion Econometric model-A Case in Vietnam Real Estate Industry', Data Science for Financial Econometrics-Studies in Computational Intelligence, vol.898, Springer. http://doi-org-443. webvpn. fjmu.edu.cn/ 10.1007/ 978-3-030-48853-6_14

14) Huy, D.T.N., An, T.T.B., Anh, T.T.K., Nhung, P.T.H. (2021). Banking sustainability for economic growth and socio-economic development - case in Vietnam, Turkish Journal of Computer and Mathematics Education, 12(2), pp. 2544-2553

15) Khwaja, Asim Ijaz., and Mian, Atif. (2005). Unchecked intermediaries:Price manipulation in an emerging stock market, Journal of Financial Economics 78, 243 - 241

16) Ton, V.D., \& Thang, P.D. (2009), "Distribution, characteristics and productivity of Ban pigs raised in Hoa Binh province", Journal of Science and Development, 2009, 7(2): 180-185.

17) Keenan, D.F. (2016). Pork Meat Quality, Production and Processing on. Retrieved from: https://www.researchgate.net/publication/301702274_Pork_Meat_Quality_Production_and_Processing_on, access date 23/6/2021). DOI: HYPERLINK "http://dx.doi.org/10.1016/B978-0-12-384947-2.00551-1" It "https://www.researchgate.net/publication/_blank" 10.1016/B978-0-12-384947-2.00551-1

18) Kvisna, Keosua, Phia Kraixeng Xrium riThailan (2005), Technical process of breeding and developing wild boar, Translation by Le Van Hien and Le Tuan Tu.

19) Kuhn. G., Kanitz. E., Tuchuscherer. M., Nurnberg. G., Hartung. M., Ender. K., Rehfeldt. C (2004), "Growth and carass quality of offspring in respose to porcine somatotropin (pST) treatment of sows during early pregnancy", Livestock production Science 85, 103-112.

20) Lan, L.T., Huy, D.T.N., Thom, B.T., \& Hang, N.T. (2021). Environment issues and feeding mechanism for wild pigs and wild pork processing during evfta in asian countries, International Journal of Ecosystems and Ecology Science (IJEES), 11(4): 685-692. 
21) Litten J. C.; a. M. Corson, A. O. Hall; L. Clarke (2004) "The relationship beetween growth performance, feed intake, endocrine profileand carcass quality of different maternal and paternal of pig", Livestock Production Science, pp. 33-39.

22) Morlein. D, Link. G, Werner. C, Wicke. M, (2007), "Suitability of three commercially produced pig breeds in Germany fora meat quality program with emphasis on drip loss and eating quality", Meat Science, 77, 504-511

23) Marsico, G., A. Rasulo, S. Dimatteo, S. Tarricone, F. Pinto and M. Ragni (2007). Pig, F1 wild boar x pig and wild boar meat quality. Italian Journal of Animal Science, 6 (suppl. 1): 700 - 703.

24) Noi, N.V. (2010), Research on polymorphisms of some genes that regulate growth and meat production ability of pigs crossed between Thai forest and Pac Nam local sows, Master's thesis in agriculture, School of Agriculture and Rural Development. Thai Nguyen University of Agriculture and Forestry, pp. 45-50.

25) Hao, P.X. (2007), Evaluation of growth, yield and meat quality in Landrace, Yorkshire and F1 pigs (Landrace x Yorkshire), Journal of Agricultural Science, 5(1): 31-35.

26) Phung, T.V., Hien, T.Q., Van, T.T., \& Hao, H.T. (2004), Textbook of pig breeding (University), Agriculture Publishing House, Hanoi, p. 16-25; 113-115.

27) Phung, L.D., \& Nguyet, H.T. (2011), Research on appearance, living habits, ability and reproductive behavior of imported Thai wild boar raised in central Vietnam, Journal of Science, Hue University, 67, 2011.

28) Pedrazolli, M., Bosco, A.D., Castellini, C., Ranucci, D., Mattiolli, S., Pauselli, M. (2017). Effect of age and feeding area on meat quality of wild boars, Italian Journal of animal science, 16(3). https://doi.org/10.1080/1828051X.2017.1292114

29) Pligne, I., Colignan, A., \& Trystram, G. (2001). Characterization of traditional processing of pork meat into boucane, Meat science, 59: 377-389.Retrieved from: http://www.pfigueiredo.org/TA34.pdf, access date 23/6/2021).

30) Son, TT., Mai, N.T., \& Hang, N.T.L. (2006), Textbook of nutrition and pet food, Hanoi Agricultural Publishing House.

31) Schneider, M. (2014). China's Pork Miracle? Agribusiness and Development in China's PorkIndustry.Retrievedfrom:https://www.researchgate.net/publication/274640306_China's_Pork_Mira cle_Agribusiness_and_Development_in_China's_Pork_Industry,accessdate23/6/2021.DOI:10.13140/ RG.2.1.3133.6489

32) Luu, T.X., Loan, T.T., Su, V.V., Thanh, N.V., \& Ngoc, T.P.Tang Xuan Luu, Tran Thi Loan, Vo Van Su, Nguyen Van Thanh and Trinh Phu Ngoc (2010), Some biological characteristics of imported Thai wild boar and Vietnamese wild boar, Journal of Science and Technology. Technology, National Institute of Livestock Production, 25, pp.12 -19.

33) Thang, H.T., \& Van. C. (2006), Textbook of animal physiology, Agricultural Publishing House, pp. 57-70.

34) Thom, B.T., \& Huy, D.T.N. (2021). Study on wild pork and pigs in thai nguyen , vietnam -and pork meat export criteria to europe, Revista geintec-gestao Inovacao E Tecnologias, 11(3): 51-65

35) Thom, B.T., \& Phung, T.V. (2013). Wild pigs project, Thai Nguyen University of Agriculture and Forestry, Vietnam

36) Thom, B.T, Huy, D.T.N., \& Phung, T.V. (2021). Improving Yield and Quality of Wild Pork and Pigs in Thai Nguyen, Vietnam - and Solutions to Enhance Competitiveness to Thailand and China, Alinteri Journal of agriculture science, 36(1): 746-752.

37) Van de Ligt C. P. A., Lindemann M. D and Cromwell G. L. (2002), "Assessment of chromium tripicolinate supplementation and dietary protein level on growth, carcass, and blood criteria in growing pigs", J. Anim. Sci. 2002, 80, pp. 2412 - 2419.

38) Giang, V.D., Hong, N.T.L., Son, T.T, 1999, Nutrition and fodder, Agriculture Publishing House, Hanoi.

39) Vietnam Livestock Association (2002), Pig Breeding Manual, Hanoi Agricultural Publishing House, p. 26-27, 70-72.

40) Wang T. C and Fuller M. F. (1990), "The effect of the plane of nutrition on the optimum dietary amino acid pattern for growing pigs", Animal Production 50, pp. 155 - 164.

41) Wang, H.S., Xia, T., \& Guan, Z. (2018). Market power and food safety in the China pork industry: Agribusiness 35(9). DOI:10.1002/agr.21591

42) Warriss, P. D. and Brown, S. N. (1995). "The relationship between reflectance EEL value and colour L" in pork loins". Animal Science, 61: 145-147. https://www.fftc.org.tw/htmlarea_file/ activities/20140314102754/ CR\%201\%20Dr.\%20Wichai\%20Tantasuparuk.pdf (access date $22 / 6 / 2021$ 